\title{
KONTRIBUSI T.M HASBI ASH-SHIDDIEQY DALAM PENGEMBANGAN ILMU AL-QUR'AN DAN TAFSIR DI INDONESIA
}

\author{
Muhammad Faisal, M.TH \\ Email: mfaisal705@yahoo.com \\ Dosen STAIN Teungku Dirundeng Meulaboh
}

\begin{abstract}
Abstrak
Kajian terhadap pengembangan Ilmu Al-Qur'an dan Tafsir di Indonesia memiliki kemajuan yang sangat pesat dari abad ke abad. Banyak kitab tafsir karya ulama Nusantara yang telah hadir hingga sampai sekarang ini. Dalam sejarah pengembangan Ilmu Al-Qur'an dan tafsir tercatat nama T.M Hasbi Ash-Shiddieqy, sosok yang sangat fenomenal dikarenakan banyaknya karya-karya beliau termasuk Ilmu Al-Qur'an dan Tafsir. Karya beliau yaitu Sejarah dan Pengantar Ilmu Al-Qur'an dan Tafsir, Ilmu-Ilmu Al-Qur'an (Ulumul Quran) serta Kitab Tafsir Al-Qur'an Majid An-Nur dan Kitab Tafsir al-Bayan merupakan karya-karya beliau yang sangat fenomenal hingga terus dikaji sampai sekarang ini. Penelitian ini bersifat kepustakaan (Library Research) yang bersifat kualitatif., kemudian metode yang diterapkan pada pengumpulan data pada penelitian ini adalah metode dokumentasi. Tahapan mengolah data dan menganalisa data yang sudah dikumpulkan, penulis menggunakan metode diskriptif analisis. Dari hasil penelitian penulis menunjukkan bahwa sosok Hasbi Ash-Shiddieqy merupakan ulama dan cendikiawan yang sangat berkontribusi besar dalam pengembangan Studi Ilmu Al-Qur'an dan tafsir di Indonesia. Ini dibuktikan dengan hadirnya karyakarya beliau yaitu sejarah dan pengantar Ilmu AlQur'an dan Tafsir,Ilmu-ilmu Al-Qur'an, serta kitab tafsir Al-Qur'an Majid An-Nur dan Kitab Tafsir alBayan. Dan terus dijadikan rujukan penelitian dan pengembangan studi ilmu Al-Qur'an dan Tafsir di Indonesia sampai sekarang.
\end{abstract}

Keywords: Kontribusi, Pengembangan, Ilmu Al-Qur'an dan Tafsir

\section{PENDAHULUAN}

Penafsiran Al-Qur'an sejatinya telah dimulai semenjak Al-Qur'an diturunkan oleh Allah kepada Nabi Muhammad SAW. Nabi Muhammad SAW merupakan penafsir Al-Qur'an pertama kali. Tentunya penafsiran pada awal-awal tersebut tidak begitu membutuhkan penjelasan yang luas, mengingat pada masa itu Al-Qur'an ditafsirkan kebanyakan dari pertanyan-pertanyaan dari sahabat yang tidak dapat memahami dari bagian-bagian Ayat Al-Qur'an. Fase perkembangan penafsiran Al-Qur'an terus berkembang ke masa selanjutnya, terlebih lagi ketika Islam berkembang dan meluas keberbagai wilayah yang dominananya wilayah tersebut diluar dari bangsa Arab. Tentunya Al-Qur'an yang berbahasa Arab sulit dipahami oleh masyarakat di luar bangsa Arab. Kemudian muncul para ulama ahli Al-Qur'an dan mulai menafsirkan ayatayat yang terdapat di dalam Al-Qur'an agar dapat dipahami oleh masyarakat seterusnya. Penafsiran Al-Qur'an dilakukan dengan kaidah-kaidah yang sederhana. 
Fase penafsiran Al-Qur'an dengan melalui metode-metode ilmiah lahir beriringan dengan berkembangnya ilmu pengetahuan dalam Islam. Sehingga lahirlah model penafsiran Al-Qur'an yang didasarkan oleh pengembangan ilmu pengetahuan. Setidaknya sampai saat ini, terdapat berbagai macam metodologi dan pendekatanpendekatan penafsiran Al-Qur'an. Di antaranya: metode ijmali, metode tahlili, metode maudhu'i, dan metode muqarran, disisi lain, dalam penafsiran Al-Qur'an juga dikenal dengan corak penafsiran, di antara corak penafsiran Al-Qur'an tersebut adalah corak fiqih, corak tasawuf, corak falsafi, corak al-adab al-ijtima’i, corak tafsir bil 'ilmi. Disamping itu terdapat berbagai macam metodologi dalam penafsiran Al-Qur'an lainnya. Ulama-ulama dan tokoh-tokoh penafsir Al-Qur'an telah banyak yang lahir dari masa awal sampai masa sekarang ini, tidak terkecuali di Indonesia, sebut saja Buya Hamka, Hasbi Ash-Shiddieqy, K.H Mustafa Al-Bisri, Quraish Shihab dan masih banyak yang lainnya.

Dalam Pembahasan ini, penulis memfokuskan pembahasan terhadap Hasbi AshShiddieqy dengan berbagai alasan, diantaranya hasbi Ashiddiqey dikenal sebagai sosok ulama yang sangat produktif pada masanya. Kontribusinya dalam pengembangan ilmu pengetahuan khususnya dalam bidang Al-Qur'an dan Tafsir dibuktikan dengan menulis buku pengantar ilmu Al-Qur'an dan Tafsir serta menulis dua kitab tafsir.

\section{PEMBAHASAN}

\section{Sejarah Penafsiran Al-Qur'an di Indonesia}

Indonesia dikenal juga sebagai salah satu negara yang banyak melahirkan ulama-ulama tafsir, dalam sejarahnya, penulisan tafsir di Indonesia telah dimulai dari beberapa abad yang lalu, dimulai dari karya Abd al-Rauf as-Singkili dengan judul kitab tafsirnya Tarjuman al-Mustafid. Kitab Tafsir ini ditulis dalam Bahasa Melayu sekitar abad ke-17, sampai dengan sekarang. Pada masa modern ini juga kajian tafsir terus meningkat dan telah melahirkan banyak kitab tafsir, diantaranya yang terkenal adalah kitab Tafsir al-Misbah karya Quraisy Syihab.

Nashiruddin Baidan dalam bukunya Perkembangan Tafsir Al-Qur'an di Indonesia membagi perkembangan tafsir di Indonesia ke dalam beberapa periode, di 
antaranya. Periode Klasik (Abad VIII-XV M). Periode Tengah (Abad XVI-XVIII M). Periode Pramodern (Abad XIX). Periode Modern (XX).

\section{Periode Klasik (Abad VIII-XV M)}

Periode klasik disini dikategorikan mulai permulaan Islam masuk ke Indonesia menurut seminar di Medan tahun 1963) yaitu sekitar abad pertama dan kedua hijriah dan berlangsung sampai abad ke-10 H. Pada masa ini penafsiran Al-Qur'an terjadi selama kurun waktu lebih kurang (Sembilan) abad yang disebut juga dengan periode klasik. Pada periode ini juga merupakan cikal bakal bagi perkembangan tafsir pada masa-masa sesudahnya.

Bentuk penafsiran pada periode ini nampaknya belum mengacu pada al-ma'sur atau $a r-r a$ 'yi karena masih bersifat umum. Hal ini disebabkan oleh kondisi kehidupan ditengah masyarakat, di mana pada saat itu umat Islam belum merupakan sebuah komunitas muslim dalam arti yang sesungguhnya. Menurut Nashiruddin jika memang dirasa perlu untuk memberikan istilah pada model tafsir di periode ini, agaknya dapat dikatakan bahwa bentuk tafsir pada masa ini berbentuk Embriotik Intergral. Artinya, pada periode ini diberikan secara intergral bersamaan dengan bidang lain, seperti fikih, teologi, dan tasawuf. ${ }^{1}$

Metode Tafsir yang digunakan pada periode ini mengisyarakat ke dalam model tafsir ijmali. Walaupun sepenuhnya belum mengikuti pola metode tafsir ijmali, tapi dalam penafsirannya dilakukan secara sederhana. Dan model tafsir pada periode ini diberikan bersifat sporadis, praktis, dan kondisional. Bisa dipahami bahwa tafsir yang diberikan pada periode ini sesuai dengan kebutuhan praktis. Corak penafsiran yang hadis pada periode ini menganut corak umum yang tidak mengacu pada satu corak tertentu sebagaimana yang terjadi pada periode-periode setelahnya ${ }^{2}$

Perkembangan penafsiran Al-Qur'an di Indonesia tentunya berbeda dengan apa yang terjadi di Timur Tengah. Perbedaan ini terjadi dikarenakan berbedanya latar

\footnotetext{
${ }^{1}$ Nashiruddin Baidan, Perkembangan Tafsir Alquran di Indonesia, (Solo: Tiga Serangkai Putra Mandiri : 2003), 32-35

2 Nashiruddin Bandan, Perkembangan..., 36-37
} 
belakang budaya dan Bahasa, karenanya. Proses penafsiran Al-Qur'an untuk bangsa Arab melalui bangsa Arab itu sendiri, sedangkan Bangsa Indonesia harus melalui penerjemahan Bahasa Arab itu sendiri ke dalam Bahasa Indonesia, setelah itu barulah diberikan penafsiran secara rinci . Bisa dikatakan dalam proses penafsiran Al-Qur'an di Indonesia melalui proses yang Panjang atau lebih lama dibandingkan dengan yang berlaku ditempat asalnya.

Bentuk tafsir Al-Qur'an yang ada di Indonesia dari masa dulu sampai dengan masa sekarang terdapat perbedaan dalam Teknik penulisannya. Karya -karya tafsir tersebut mengalami perubahan yang menarik, baik dari segi penyampaian, tema-tema kajian, serta sifat mufassir. Secara umum dalam kajian Ilmu tafsir dikaitkan dengan metodologi Penafsiran Al-Qur'an yaitu, metode penafsiran, sumber penfasiran dan corak atau pendekatan dalam penafsiran

\section{Periode Tengah (Abad XVI-XVIII)}

Pada periode ini bentuk tafsir sudah mulai mengalami perkembangan, di mana pada periode ini tidak lagi mengandalkan ingatan dalam menafsirkan Al-Qur'an, tetapi sudah mulai berkenalan dengan kitab-kitab tafsir yang didatangkan dari timur tengah, seperti kitab tafsir jalalain.Kitab tafsir ini didatangkan oleh para guru kemudian diajarkan kepada murid-muridnya lalu diterjemahkan kedalam bahasa (Melayu, Jawa, dan sebagainya). Adapun pola tafsir yang berkembang pada periode ini berkembang sesuai dengan pola tafsir yang terdapat pada corak tafsir yang pada kitab tafsir yang dibacakan. $^{3}$

Model tafsir pada periode ini lebih berkembang dan lebih dapat dipertanggungjawabkan secara ilmiah karena tidak didasarkan kepada ingatan sebagaimana yang berlaku pada model tafsir pada periode klasik, juga pada periode ini telah memiliki kitab tafsir pegangan yang representatif dari ahli tafsir. Pola penafsiran ini berkembang lebih kurang selama tiga abad (XVI-XVIIIM). Bentuk tafsir pada periode ini menurut Nashiruddin Baidan dengan mengambil contoh model tafsir Tafsir Jalalain adalah dengan bentuk tafsir ( $\left.a r-R a^{\prime} y u\right)$ dalam bentuk pemikiran. Bukan secara bil ma'stur (Riwayat). Adapun metode tafsir yang diterapkan pada periode ini bisa

\footnotetext{
${ }^{3}$ Nashiruddin Baidan, Perkembangan....,38-39
} 
dikatakan tidak berbeda dengan metode tafsir pada periode klasik dimana tetap menggunakan metode tafsir ijmali (global). Sedangkan corak tafsir pada periode ini masih seperti pada periode yang lalu bersifat umum yang tidak mengacu pada pemikiran tertentu, namun walaupun demikian model penafsiran Al-Qur'an pada periode ini telah mengacu pada kitab Tafsir Jalalain dengan melakukan penelaahan terhadap kitab tafsir tersebut. Sehingga corak tafsir yang dikaji adalah corak tafsir yang terdapat dalam kitab Tafsir Jalalain. ${ }^{4}$

Pada periode ini juga telah berkembang penulisan terjemahan Al-Qur'an ke dalam bahasa-bahasa yang telah dipakai oleh para murid-muridnya, seperti Bahasa Jawa, Madura dan Melayu. Hal ini didasarkan pada sebuah manuskrip terjemahan Surat al-Ma'arij ke dalam Bahasa Maduradari ayat 1-10. Manuskrip ini ditulis pada kertas kayu sehingga diprediksi manuskrip terjemahan ini ditulis pada abad ke-16 sampai dengan abad ke-18 M. Disisi lain juga pada periode ini selain adanya terjemahan AyatAyat Al-Qur'an, juga adanya penafsiran Al-Qur'an seperti yang dilakukan oleh AbdurRauf Ali An-Fanshuri (Abad XVII M) dengan judul kitab Tafsirnya Tarjuman AlMustafid yang awalnya kitab tafsir ini dianggap sebagai terjemahan kitab tafsir karya alBaidhawi yakni kitab tafsir Anwarut-Tanzil wa Asrarut-Takwil. Namun, setelah diteliti secara mendalam ternyata kitab tafsir tersebut bukan dari terjemahan kitab tafsir Baidhawi. Akan tetapi kitab tafsir karangan An-Fanshuri sendiri, namun di didalam kitab tafsir tersebut An-Fanshuri didalamnya terdapat kutipan kitab tafsir al-Baidhawi. ${ }^{5}$

Bentuk kitab tafsir Tarjuman al-Mustafid ini mengacu pada Kitab Tafsir alBaidhawi, yang menurut para ulama tafsir, seperti az-Zahabi menilai kitab tafsir alBaidhawi ini berbentuk ra'yu (pemikiran) dengan didukung riwayat-riwayat berupa hadis atau atsar, qira'at dan sebagainya, kesimpulan ini didapat dari penafsiran Surat AlFatihah, awal surat Al-Baqarah, sampai dengan surat terakhir An-Nas. Kitab tafsir Tarjuman al-Mustafid ini hanya mengambil kutipan dari kitab Tafsir Baidhawi. Ia hanya mengukitp ide pokoknya saja, sehingga yang dianggapnya tidak terlalu penting maka tidak dikutip. Metode penafsiran yang dilakukan oleh al-Fanshuri dalam kitab tafsirnya Tarjuman al-Mustafid menggunakan metode analitis (tahlili), sedangkan corak

\footnotetext{
${ }^{4}$ Nashiruddin Bandan, Perkembangan..., 54-55

${ }^{5}$ Nashiruddin Bandan, Perkembangan..., 62
} 
tafsir yang terdapat dalam kitab tafsir tersebut menggunakan corak umum. Artinya, tafsiran yang diberikan tidak mengacu kepada corak tertentu misalnya corak fikih, tasawuf,falsafi, dan adab al-Ijtima'i.

\section{Periode Pramodern (Abad XIX)}

Model Penafsiran pada periode ini tidak jauh berbeda dengan periode sebelumnya. Secara substansi tafsir mereka sama karena sama-sama memakai kitab Tafsir al-Jalalain dalam pengajaran Tafsir pada anak didik mereka. Berdasarkan faktafakta yang terdapat pada periode ini sampai pada abad ke-19 tidak lahir mufassirmufassir dalam arti yang sesungguhnya karena mereka hanya diperkenalkan pada satu kitab tafsir saja, yakni kitab Tafsir Jalalain sedangkan kitab Tafsir Tarjuman alMustafid yang telah disebutkan sebelumnya tidak begitu popular dipesantren pada umumnya. Setelah al-Fanshuri menerbitkan Kitab Tafsir Tarjuman al-Mustafid pada abad ke-17 prakris selama kurang lebih dua abad ini adanya kevakuman dalam penafsiran Al-Qur'an bagi Bangsa Indonesia pada masa itu. Sebanarnya ada factor yang bisa dikatakan sebagai penghambat dalam kajian penafsiran Al-Qur'an. salah satu faktornya yaitu, adanya penjajahan yang dilakukan oleh pihak belanda. Aktifitas pengajian, dakwah dan Pendidikan Islam masih sangat ketat dalam pengawasan pihak belanda. ${ }^{6}$

Pada masa ini, bisa dikatakan kehidupan umat terutama pada abad (ke 18 dan ke-19). Penuh ketakutan dan kekhawatiran untuk mengeluarkan ide-ide yang bertentangan dengan penjajah. Tentunya dalam kondisi seperti ini jelas sulit diharapakan adanya tafsiran-tafsiran Al-Qur'an yang luas dan kondusif dengan budaya bangsa Indonesia.

\section{Periode Modern (Abad XX)}

Pada Abad ke-20 ini bisa dikatakan sebagai periode timbulnya gairah untuk kajian tafsir terhadap Al-Qur'an di Indonesia. Pada periode ini memberikan kontribusi besar terhadap upaya penafsiran Al-Qur'an jika dibandingkan dengan abad-abad sebelumnya. Pada abad ini dibagi menjadi beberapa waktu. Pertama, mulai dari tahun

\footnotetext{
${ }^{6}$ Nashiruddin Bandan, Perkembangan..., 80
} 
1900 sampai dengan 1950. Kedua, Tahun 1951 sampai dengan tahun 1980, dan ketiga 1981 sampai tahun $2000 .^{7}$

Antara tahun 1900 sampai dengan 1950. Banyaknya para ulama-ulama Indonesia yang belajar di Timur Tengah kemudian membawa ide-ide pembaharuan tafsir dari sana. Seperti. K.H Ahmad Dahlan, K.H. Hasyim Asy’ari dan Syekh Sulaiman Ar-Rasuli. Dimana masing-masing tokoh tersebut setelah belajar di Timur Tengah kemudian Kembali ke Indonesia dan mendidirikan tempat-tempat pengajian atau Lembaga Pendidikan Islam. Serta mendirikan organisasi-organisasi yang terkenal hingga pada masa sekarang. Lembaga tersebut sangat berpengaruh dalam proses penafsiran Al-Qur'an. setidaknya pada abad ini. Telah lahir mufassir-mufassir dari Indonesia. Diantaranya, 1). A.Hassan Bandung dengan kitab tafsirnya Al-Furqan $f i$ Tafsiri Al-Quran. 2) Al-Qur'an Indonesia oleh Syarikat Kweek School Muhammadiyah bagian karang mengarang (1932 M). 3) Iskandar Idris dengan kitab Tafsirnya Tafsir Hibarna (1934 M). 4) K.H Sanusi dengan kitab Tafsirnya Tafsir Asy-Syamsiyah (1935 M). 5) Prof. Dr. Mahmud Yunus (1938 M) dengan kitab Tafsir Qur'an Karim. 6) Mahmuz Aziz dengan kitab Tafsir Qur'an Bahasa Indonesia (1942). ${ }^{8}$ Umumnya metode Tafsir yang digunakan oleh keenam kitab tafsir ini bersifat terjemahan daripada tafsir secara luas dan terperinci. Artinya metode tafsir yang digunakan adalah Ijmali (umum). Namun terdapat juga pada ayat-ayat tertentu yang dirasa memerlukan tafsir yang lebih terperinci lagi sebagaimana yang dilakukan oleh Mahmud Yunus Ketika menjelaskan surat An-Nur ayat 31. Juga dalam corak tafsir umumnya penafsiran yang dilakukan bersifat umum. ${ }^{9}$

\section{Kurun Waktu kedua (1951-1980)}

Pada Periode ini, dapat dikatakan adanya perkembangan Tafsir Al-Qur'an yang lebih baik dan lebih merespon tantangan zaman. Hal ini dibarengi dengan berkembangnya Lembaga Pendidikan, seperti berdirinya Perguruan Tinggi Islam. Dengan adanya Perguruan Tinggi Islam ini diharapkan akan terjadinya peningkatan khazanah intelektual Islami yang amat berarti, termasuk didalamnya kajian tafsir Al-

\footnotetext{
${ }^{7}$ Nashiruddin Bandan, Perkembangan..., 81

${ }^{8}$ Nashiruddin Bandan, Perkembangan..., . 88

${ }^{9}$ Nashiruddin Bandan, Perkembangan..., 92-93
} 
Qur'an selain itu peningkatakan kajian tafsir pun meningkat secara non-formal dengan adanya kegiatan pengajian Tafsir Al-Qur'an, seperti majelis-majelis Tafsir, MTA (Majelis Tafsir Al-Qur'an) yang berpusat di Surakarta. Pada masa ini juga lahir beberapa kitab tafsir. Di antaranya: 1) Tafsir Quran oleh Zainuddin Hamidi CS (1963). 2) Tafsir Sinar oleh Malik Ahmad, 3) Tafsir al-Azhar karya Prof. Dr. Hamka (1966). 4) Al-Qur'an dan Terjemahnya oleh Yayasan Penterjemahan Al-Qur'an Departemen Agama RI. (1967). 5) Tafsir Bayan (1971), Tafsir An-Nur (1973) oleh Prof. T.M Hasbi ash-Shiddieqy, 6) Al-Qur'an dan Terjemahannya oleh Redaksi Penerbit Bahrul Ulum pimpinan Bakhtiar Surin, 7) Al-Qur'an Bacaan Mulia oleh Dr. H. B Jassin (1977). Pada periode ini juga lahir kitab-kitab tafsir yang dikarang dalam Bahasa selain Bahasa Indonesia. Di antaranya, 1) al-Kitabun al-Mubin karya K.H. Muhammad Ramli dalam Bahasa Sunda (1974) dan kitab Ibriz karya K.H. Mustafa al-Bisri dalam Bahasa jawa (1950). ${ }^{10}$

Umumnya dari aspek bentuk penafsiran terhadap Al-Qur'an yang terdapat pada periode ini menggunakan bentuk pemikiran ( $\left.r a^{\prime} y i\right)$. Dan dari segi Metode Penafsiran Al-Qur'an telah menggunakan dua metode yakni metode ijmali dan metode tahlili . sementara corak tafsir yang berkembang pada kitab-kitab tafsir yakni secara umum tidak menetapkan pada suatu corak tertentu, kecuali pada kitab tafsir al-azhar karya Buya Hamka yang bercorakan Sosial Kemasyarakatan ${ }^{11}$

Periode ketiga (1981-2000)

Pada periode ini khususnya pada lembaga Pendidikan formal yakni pada Perguruan Tinggi Islam, sudah mulai ditingkatkan dengan adanya pembukaan program S2 dan S3 sebagai upaya untuk menghasilkan outcometafsir yang lebih berkualitas. Pada masa ini lahir salah satu kitab tafsir yang terkenal yaitu kitab tafsir al-Misbah karya Prof.Dr. H. M. Quraish Shihab, MA. Pada masa ini model penafsiran Al-Qur'an berbentuk pemikiran (ar-ra'yu) dengan metode analitis dasn corak umum. Tafsir al-Fatihah karya

\footnotetext{
${ }^{10}$ Nashiruddin Bandan, Perkembangan..., 100-101

${ }^{11}$ Nashiruddin Baidan, Perkembangan..., 100-106
} 
Quraish Shihab dan Mu'in Salim dapat dikelompokkan Tafsir Tematik (maudhu'i). Karya Nashiruddin Baidan berisi metode Tafsir perbandingan ${ }^{12}$

Pengembangan Ilmu Alqura dan Tafsir pada masa ini terus menjadi hal yang mengagumkan dimana metode dan corak tafsir semakin berlkembang dan semakin bervariasi dibandingkan dengan abad-abad dan tahun-tahun sebelumnya, maka para pakar tafsir yang terus lahir dari Lembaga-lembaga pendidikan baik itu formal maupun non formal.

Dalam studi Kajian Ulumul Quran di Indonesia tidak terlepas dari perkembangan tafsir Al-Qur'an itu sendiri, dimana menurut para peneliti tafsir-tafsir yang berkembang di Indonesia telah memberikan warna serta wawasan baru dalam perkembangan Studi Ilmu Al-Qur'an di Indonesia. Khususnya kajian serta pembahasan UlumulQuran di Indonesia, telah masuk perguruan tinggi serta mulai aktif menjadi bahan kajian semenjak dibukanya program studi Ilmu Tafsir Hadits yang menjadi central perkembangan Ulumul Qu'ran. Buku Al-Qur'an dari masa ke masa karya Munawir Khalil yang terbit pada tahun 1953 dan Sejarah Al-Qur'an karya Abu Bakar Atjeh yang diterbitkan pertama kali pada tahun 1967. Kedua buku ini merupakan karya yang menjadi konsep kajian Al-Qur'an pertama. Dimana dalam bukunya Abu Bakar Athjeh membahas tentang Al-Qur'an memiliki peran utama yaitu meningkatkan kualitas keyakinan dan memperluas keimanan, sebagai dasar pijakan hukum. Sedangkan Munawar klali dalam bukunya membahas mengenai jumlah ayat dalam Al-Qur'an yang terdiri dari 1456 ayat dari 86 Surat yang diturunkan pada periode Makkah dan 431 ayat dari 28 surat yang diturunkan pada periode Madinah. ${ }^{13}$

Para peneliti mencatat sebagaimana yang disebutkan oleh Izza Rohman, setidak terdapat 654 referensi dalam studi Al-Qur'an, di antaranya terdiri dari 285 referensi yang berbahasa Arab, 203 berbahasa Indonesia, dan 157 berbahasa asing (selain dari Bahasa Arab dan Indonesia). ${ }^{14}$ Muhsin dalam penelitian menyebutkan ada sekitar 20

${ }^{12}$ Nashiruddin Baidan, Perkembangan...,110

13 Muhsin, "Kajian Karya-Karya Ulum Alquran di Indonesia Dari Tahun 2009-2017” Jurnal Syahadah, Vol, VI, No. 1. April 2018, 66. Federspiel, Kajian Alquran di Indonesia dari Mahmud Yunus hingga Quraish Shihab, (Bandung: Mizan 1996), 112-115.

${ }^{14}$ Izzaa Rohman Nahrowi, "Karakteristik Kajian al-Qur'an di Indonesia” Jurnal Refleksi, vol. v, No.2 
karya 'Ulumul Qur'an. Di mana isi dari buku ulumul quran tersebut hamper seragam tanpa ada tambahan. ${ }^{15}$

Dari penjelasan di atas, bisa ditarik kesimpulan bahwa kajian terhadap studi Ilmu Al-Qur'an dan Tafsir berkembang secara beriringan namun kajian terhadap Tafsir lebih dominan, hal ini bisa dilihat dari abad-abad karya terhadap penafsiran Al-Qur'an terus meningkat, tetapi menurut hemat penulis, Ilmu Al-Qur'an dan Tafsir tidak dapat dipisahkan antara satu dengan lainnya tetap mendukung antara keduanya. Namun, secra sederhana kajian Tafsir lebih dominan dikarenakan umat Islam memerlukan pemhaman terhadap Al-Qur'an yaitu dari segi tafsirnya, secara praktis dimana ulama tafsir tidak menkonsepkan kajian Ilmu Al-Qur'an dan menjelaskan Ilmu-ilmu tersebut, namun lebih memberikan pemahaman secara langsung terhadap ayat-ayat Al-Qur'an. Kondisi ini jelas berbeda terutama dimana sekarang dengan semakin banyaknya kajian Ilmu AlQur'an di tingkat perguruan tinggi, Ilmu Al-Qur'an perlu dikonsepkan dan dipelajari secara sistematis sehingga bagi sarjana-sarjana yang menekuni Kajian Tafsir harus memahami Ilmu-Ilmu Al-Qur'an sebagai bekal untuk menafsirkan Al-Qur'an.

\section{Literatur Review}

Sejatinya pengkajian mengenai tafsir T.M Hasbi Ash-Shiddieqy telah banyak dilakukan terhadap dua kitab tafsir beliau baik kitab tafsir Al-Qur'an Al-Majid An-Nur dan Tafsir al-Bayan. Di antaranya tulisan dari Sulaiman Ibrahim dengan judul Khazanah Tafsir Nusantara: Telaah atas Tafsir Al-Bayan Karya T.M Hasbi AshShiddiqiey. Dalam tulisan mengenai kitab Tafsir Al-Bayan, bahwa kitab tafsir an-Nur lahir dari dua factor. Faktor Intern dan faktor ekstern. Faktor intern yaitu sebagai upaya pengembangan Tafsir an-Nur sedangkan factor estern, yakni sebagai upaya dalam rangka penyermpurnaan kata-kata. Tafsir al-Bayan berisi tafsiran ayat-ayat Al-Qur'an secara utuh (30 juz 114 surah), yang menggunakan penafsiran Al-Qur'an secara analitis, yakni bersifat metode Tafsir al-Tahlily. Adapun bentuk penulisan tafsir yang terdapat di

\footnotetext{
${ }^{15}$ Muhsin, Kajian Karya-Karya Ulum Alquran..., h. 66
} 
dalam tafsir al-Bayan ini adalah bentuk tulisan yang bercorak al-Ra'yi (pemikiran) dan corak tafsir fiqih (hukum). ${ }^{16}$

Tulisan lainnya ditulis oleh Sudariyah dengan judul Kontruksi Tafsir Al-Qur'an Majid An-Nur Karya M. Hasbi Ash-Shiddiqey. Dalam tulisannya Sudariyah berkesimpulan bahwa Tafsir An-Nur memiliki kekhususan tersendiri dibandingkan dengan kitab tafsir lainnya, di samping ia merupakan seoarang ulama yang sangat kompeten dalam bidang keilmuannya, tafsir ini memiliki ciri khas fikih keindonesiaan. Dalam proses penafsiran Al-Qur'an Hasbi tidak begitu saja menerima hukum tersebut secara tekstual atau pun menafsirkan ayat-ayat hukum tersebut sesuai dengan mazhab yang dianutnya yaitu mazhab Syafi'I, melainkan juga ia berusaha menampilkan dan menguraikan tentang berbagai Riwayat atau pendapat para ulama yang sesuai dengan tema, kemudian setelah itu Hasbi mengaitkan dengan konteks kehidupan masyarakat Indonesia yang sangat pluralistic. Dengan begitu, penafsiran yang dilakukan Hasbi dapat dengan mudah dipahami oleh masyarakat Indonesia. ${ }^{17}$

A.M.Ismatulloh dengan judul tulisannya Penafsiran M.Hasbi Ash-Shiddiqey Terhadap Ayata-Ayat Hukum Dalam Tafsir An-Nur. Dalam Tulisannya, A.M.Ismatulloh berkesimpulan bahwa Penafsiran yang dilakukan oleh Hasbi menggunakan bentuk tafsir bi lar-ra' yi. Metode yang digunakan adalah metode tahlili yaitu secara rinci menafsirkan ayat demi ayat sesuai dengan urutan ayat dan surat yang terdapat dalam mushaf dan menjelaskan dari berbagai aspek. Adapun dari segi corak penafsiran, Hasbi cenderung menggunakan corak tafsir bil Ma'stur. Hal ini dapat dibuktikan dengan melihat karakteristik umum dari metode seperti melakukan penafsiran ayat dengan ayat, menafsirkan ayat Al-Qur'an dengan hadis dan menafsirkan Al-Qur'an dengan pendapat sahabat atau tabi'in. ${ }^{18}$

Berdasarkan dari literatur review yang telah disebutkan diatas. Pembahjasan mengenai T.M Hasbi Ash-Shiddieqi, sudah banyak yang mengakajinya baik dari segi

\footnotetext{
${ }^{16}$ Sulaiman Ibrahim, "Khazanah Tafsir Nusantara: Telaah atas Tafsir al-Bayan karya T.M Hasbi Ash-Shiddiqey," Jurnal Farabi, Vol 18. No. 2.2018. 115

${ }^{17}$ Sudariyah, "Kontruksi Tafsir Alquran Majid An-Nur" SHAHIH, Vol.3, No.1, 2018. 105

18 A.M. Ismatullah, "Penafsiran M.Hasbi Ash-Shiddieqy Terhadap Ayat-Ayat Hukum Dalam Tafsir An-Nur," MAZAHIB, Vol.XIII.2014. No.2. 151
} 
Tafsir, Fikih dan sebagainya. Namun. Judul yang penulis angkat sejauh penelusuran penulis belum ada yang mengkajinya.

\section{Metodologi Penelitian}

Penelitian ini bersifat kepustakaan (Library Research) yang bersifat kualitatif. Adapun Langkah yang digunakan dalam tahapan ini adalah dengan menumpulkan data dan menelaah buku-buku, literatur-literatur sehingga menghasilkan data yang dibutuhkan untuk memecahkan masalah yang dirumuskan. Sumber data yang digunakan dalam penelitian ini terdiri dari sekunder dan primer, Adapun yang menjadi sumber primer adalah karya-karya T.M. Hasbi Ash-Shiddiqey dalam bidang Al-Qur'an dan Tafsir, yaitu Sejarah dan Pengantar Ilmu Al-Qur'an dan Tafsir, Ilmu-Ilmu Al-Qur'an, Tafsir Al-Qur'an Majid An-Nur, Tafsir al-Bayan, sedangkan untuk data sekunder diambil dari karya-karya T.M. Hasbi Ash-Shiddiqey dalam bidang keilmuan Islam secara umum. Disamping itu, juga akan diambil dari karya-karya lainnya yang relevan.Adapun pengumpulan data dilakukan dengan menelusuri literature primer yaitu buku-buku Hasbi Ash-Shiddiqey yang berkaitan dengan ilmu Al-Qur'an dan Tafsir, kemudian metode yang diterapkan pada pengumpulan data pada penelitian ini adalah metode dokumentasi Tahapan mengolah data dan menganalisa data yang sudah dikumpulkan, penulis menggunakan metode diskriptif analisis. Metode ini digunakan dalam penelitian ini bertujuan untuk menjelaskan suatu keadaan, peristiwa, objek ataupun segala sesuatu yang berkaitan dengan variable-variabel yang bisa dijelaskan. ${ }^{19}$

\section{Biografi Hasbi Ash-Shiddiqey, Kontribusinya Dalam Pengembangan Ilmu Al- Qur'an Dan Tafsir}

\section{Biografi Hasbi Ash-Shiddieqy}

Sosok Hasbi Ash-Shiddieqy seorang ulama yang terkenal tidak hanya di wilayah Aceh tetapi juga di wilayah Indonesia telah berkontri besar dalam memajukan Ilmu Pengetahuan khususnya dalam bidang Agama, telah banyak buku-buku yang dilahirkan oleh sosok Hasbi Ash-Shiddiqiy. Untuk mengenall lebih erat dengan sosok Hasi 2010), 36 .

${ }^{19}$ Setyosar Punaji, Metode Penelitian Pendidikan dan Pengembangan, (Jakarta: PT. Kencana, 
baiknya kita perlu melihat biografinya. Hasbi bernama lengkap Teungku Muhammad Hasbi Ash-Shiddieqy. Hasbi dilahirkan dikota lhoksemawe Aceh Utara pada tanggal 10 Maret 1904. Ayahnya bernama al-Hajj Teungku Muhammad Husayn bin. Muhammad Su'ud yang bmerupakan seorang ulama yang terkenal pada masanya. Beliau memeiliki sebuah Dayah (pesantren) dan seorang Qadi Chik, Husein Ibn Mas'ud berasal dari sebuah keluarga besar Teungku di Seumilik, Kecamatan Samalanga, Kawadean Bireuen, Aceh Utara, Ayahnya mempunyai silsilah sampai pada sahabat Abu bakar asShiddiq, sahabat, mertua dan khalifah pertama Nabi Muhammad SAW. ${ }^{20}$ sosok Ibunda Hasbi bernama Teungku Amrah, Puteri Teungku Abdul Aziz pemangku jabatan Qadhi Chik Maharaja Mangkubumi Keusltunan Aceh waktu itu. Ibunya juga merupakan keponakan Abdul Jalil yang bergelar Teungku Chik di Awe Geutah di mana menurut masyarakat di daerah tersebut khususnya di Aceh utara di anggap sebagai wali yang dikeramatkan, kuburannya hingga saat ini masih diziarahi untuk meminta berkah. ${ }^{21}$

Sebagai keturunan Abu Bakar Shiddiq, Hasbi melekatkan gelar ash-Shiddieqy dibelakang Namanya. Nama Ash-Shiddieqy dia letakkansejak tahun 1925 atas saran gurunya yang bernama Syaikh Muhammad bin Salim al-Kalali, seorang pembaharu Islam dari Sudan yang bermukim di Lhokseumawe, Aceh ${ }^{22}$. Adapun silsilah Hasbi ashShiddiqiey hingga sampai ke Abu Bakar adalah Muhammad bin Muhammad Husain bin Muhammad Su'ud bin Muhammad Taufiq ibnu Fatimi ibnu Ahmad ibnu Dhiyauddin ibnu Muhammad Ma'shum (Faqir Muhammad) ibnu Khawajaki ibnu Muhammadf Darwis ibnu Muhammad Zahid ibnu Marwajuddin ibnu Ya'kub ibnu 'Alauddin ibnu Bahauddin ibnu Amir ibnu Bahauddin ibnu Amir Kalil ibnu Syammas ibnu Abdul Aziz ibnu Yazid inu Ja'far ibnu Qasim ibnu Muhammad ibnu Abu Bakar Ash-Shiddiq. ${ }^{23}$

Masa kelahiran Hasbi dan pertumbuhannya bersamaan dengan tumbuhnya Gerakan pembaharuan pemikiran di Jawa yang menampilkan semangat perjuangan keIndonesia-an dan anti kolonial. Sementara di Aceh sendiri peperangan dengan Belanda

\footnotetext{
${ }^{20}$ Masnun Tahir, "Pemikiran T.M Habi Ash-Shiddiqey sumber hukum Islam dan Relevansinya dengan Pemikiran Hukum Islam di Indonesia" Jurnal al-Ahwal, Vol. 1, No. 1, 2008, 123

21 Nourouzzaman Shiddieqy, Fikih Indonesia: Penggagas dan Gagassannya (Yogyakarta, Pustaka: Pelajar, 1997), 3.

${ }^{22}$ Nourouzzaman Shiddieqy, Fikih Indonesia: Penggagas..., 7.

${ }^{23}$ Aan Supian. "Kontribusi Pemikiran Hasbi Ash-Shiddiqiey Dalam Kajian Ilmu Hadis." Jurnal Mutawatir, Vol.4, No.2. 2014. 187.
} 
kian berkecamuk. Saat Hasbi berusia 6 tahun, ibunya, Teungku Amrah, meninggal dunia. Setelah ibunya meninggal, Hasbi di asuh oleh bibinya yang bernama Teungku Shamsiah. Setelah bibinya meninggal pada tahun 1912, Hasbi memilih tinggal dirumah kakaknya, Teungku Maneh, bahkan sering tidur di meunasah sampai kemudian dia pergi meudagang (nyantri) dari dayah ke dayah. ${ }^{24}$

Pada umur Sembilan belas tahun, Hasbi menikah dengan seorang gadis bernama Siti Khadijah. Siti Khatijah merupakan seorang gadis yang memiliki kekerabatan dengannya. Gadis yang merupakan pilihan orang tuanya ini tidak berlangsung lama. Istrinya meninggal Ketika melahirkan anaknya yang pertama. Kemudian Hasbi menikah dengan Teungku Nyak Asiyah binti Teungku Haji Hanum, saydara sepupunya. Bersama dengan istrinya inilah Hasbi menjalani bahtera kehidupan rumah tangga sampai akhir hayat. dari perkawinananya yang kedua inilah hasbi memiliki empat anak, dua laki-laki dan dua perempuan.

Sosok Hasbi yang membebaskan diri lingkungan tradisi telah diperlihatkannya sebelum dia merangtau. Hasbi tidak menghiraukan larangan ayahnya untuk tidak bergaul bebas dengan teman-teman sebayanya. Ia tidur bersama teman-temannya tersebut di meunasah. Sikap hasbi yang kritis dan suka protes diperlihatkannya dengan carta mengincingi air kolam (kulah besar) yang sudah kotor, padahal kolam tersebut digunakan oleh para santri untuk mandi dan berwudhu. Dengan dikencingi secara terbuka, dengan terpaksa kolam tersebut dikuras dan dibersihkan. Sikap-sikap tersebut inilah yang nanti membuat sosok Hasbi Ash-Shiddieqy menolak untuk bertaklid bahkan berbeda paham dengan orang yang sealiran dengannya.

Sejak kecil Hasbi termasuk anak yang sudah memperlihatkan kecerdasannya terutama dalam bidang keagamaan. Karenanya ayah Hasbi mengharapkan ia menjadi seorang ulama, sehingga ia dilarang masuk sekolah Gubernemen, karena takut dipengaruhi pikiran Nasrani.

Sebagai putra Teungku yang memiliki Dayah, Hasbi sejak kecil mendapat pendidikan dasar langsung dari ayahnya sendiri hingga Hasbi bisa memperoleh

\footnotetext{
${ }^{24}$ Aan Supian. Kontribusi Pemikiran.., 273
} 
perhatian yang lebih seksama, hati yang terang dan kemampuan otak yang cerdas, memungkinkan Hasbi lebih cepat menguasai pokok-pokok pelajaran yang diberikan. ${ }^{25}$

Sebagai seorang anak yang diharapkan oleh ayahnya untuk menjadi seorang pakar dalam bidang keagamaan (ulama), ia dikirim oleh ayahnya untuk meudagang (nyantri) selama 8 tahun, mulai tahun 1912, Hasbi dikirim meudagang ke berbagai Dayah untuk belajar ilmu-ilmu agama. Diantara Dayah-Dayah tersebut adalah Dayah Teungku Cik di Piyeung untuk belajar Bahasa Arab, khususnya Nahwu dan Sharaf. Kemudian setelah itu ia belajar ke Dayah Teungku Cik di Bluk Bayu. Setahun kemudian ia pindah ke Dayah Teungku Cik di Blang Kabu Gendong. Kemudian ia pindah lagi ke Blang Manyak sama Kurok dan belajar selama setahun disana. Semua dayah yang telah disebutkan di atas berada di bekas Kerajaan Samudra Pasai Tempo dulu.

Setelah Hasbi merasa keilmuan dasarnya telah dirasa cukup, ia pun melanjutkan pengembaraan mencari ilmu, pada Tahun 1916 ia pergi merantau ke Dayah Teungku Cik di Tanjungan Barat yang bernama Idris, di Samalanga. Dayah ini merupakan salah satu dayah terbesar dan terkemuka di Aceh Utara yang memfokuskan kajian keilmuannya pada persoalan fikih. Hasbi belajar disini selama dua tahun, setelah itu ia pindah ke Kroengkak di Aceh Rayeuk untuk belajar Hadis dan Fikih selama dua tahun. Pada tahun 1921, dari Teungku Cik Hasan Kroengkak, ia memperoleh pengakuan (syahadah) sebagai tanda ia telah cukup dan berhak mendirikan dayah sendiri, setelah ia pulang ke Lhokseumawe. ${ }^{26}$

Sekembalinya dari perantauan dalam menuntut ilmu, khusunya Dari Dayah Kroengkak, Hasbi berjumpa dengan Syaikh Muhammad Ibnu Salim al-Kalaly yang merupakan seorang ulama besar berkebangsaan Arab, ia pernah memimpin Majalah alImam, pembawa suara al-Manar di semenanjung Melayu, yang terbit pada tahun 19061910 di Singapura. Ulama yang memberi pengaruh besar dalam pengembangan keilmuan Hasbi Ash-Shiddieqy. Dari Ulama ini Hasbi banyak mendalami kitab, seperti

\footnotetext{
25 Masnun Tahir, Pemikiran T.M. Hasbi Ash-Shiddieqy..., 124. Abdul Aziz Dahlan (ed), Ensklipodia Hukum Islam, (Jakarta: PT Ikhtiar Baru Van Hoeve), 130.

${ }^{26}$ Masnun Thahir, Pemikiran T.M. Hasbi Ash-Shiddieqy...,.124.
} 
Nahwu-Saraf, Mantik Tafsir, Hadis, Fikih dan Tauhid serta mulai berkenalan dengan ide-ide pembaharuan yang dicetuskan oleh para pelopor pembaharu pemikiran Islam. ${ }^{27}$

Hasbi merupkan sosok pribadi yang haus dalam menuntut ilmu, Ilmu-ilmu yang telah didapatinya selama menuntut di Dayah-Dayah yang pernah dia singgahi, merasa belum cukup ia pun merantau lagi untuk menuntut ilmu tepatnya pada tahun 1926, atas biaya mertuanya, Teungku Haji Arba, ia bertolak ke pulau Jawa tepatnya di Kota Surabaya. Di kota tersebut ia masuk ke Madrasah al-Irsyad pada kelas yang terakhir. Saat itu al-Irsyad ini dipimpin oleh Umar Hubes, salah satu murid Ahmad Sukarti yang merupakan pendiri dan Pembina Jam'iyyatul Islah wa al-Irsyad al-Arabiya, murid dan pengikut Muhammad Abduh. Di Madrasah ini, ia memerdalam kemampuan Bahasa Arabnya dan juga ilmu Syariah, ia banyak memperoleh inspirasi dalam bidang ini. Pada tahun 1927, Hasbi dianggap telah menyelesaikan pelajarannya dan iapun dinyatakan lulus dengan baik.

Setelah menyelesaikan pengembaraan ilmunya, ia pun mulai merintis karir, dimana Hasbi mengawli karirnya sebagai guru pada kursus yang dikelola oleh Jong Islamic Bond Daerah Aceh (JIBDA), sekolah HIS dan MULO Muhammadiyah. Tepatnya pada tahun 1948, Hasbi diminta oleh Bupati Aceh Utara menjadi guru dan memimpin Sekolah Menengah Islam (SMI). Pada tahun itu juga ia mendapat tawaran dari MENAG, K.H. A. Wahid Hasyim untuk menjadi tenaga pengajar pada PTAIN Yogyakarta. Di sela-sela kesibukan mengajar ia juga mengajar di Sekolah Guru Agama Hakim (PHIM). Madrasah Muallimin Muhammadiyah, SMI yang berpusat di Mesjid Kauman. ${ }^{28}$

Tampaknya Hasbi Ash-Shiddieqy mulai meniti karir yang lebih konsen di Perguruan Tinggi. Ketika keluar KEPRES No.11 Tahun 1960 terjadi peralihan dari PTAIN menjadi IAIN. Hasbi Ash-Shiddiqey berangkat ke Yogyakarta pada tahun 1960. Ia diangkat sebagai Dekan di Fakultas Syariah Sunan Kalijaga Yogyakarta. Jabatan ini ia pegang hingga tahun 1972. Pada Tahun 1962. Hasbi juga merangkat sebagai Dekan Fakultas Syariah IAIN Ar-Raniry Banda Aceh. Ia juga pernah menjabat sebagai Dekan

\footnotetext{
${ }^{27}$ Masnun Thahir, Pemikiran T.M. Hasbi Ash-Shiddieqy..., 125.

${ }^{28}$ Masnun Thahir, Pemikiran T.M. Hasbi Ash-Shiddieqy...., 125.
} 
Fakultas syari'ah Universitas sultan Agung di Semarang dan Rektor Universitas alIrsyad di Surakarta tahun 1963-1964, ${ }^{29}$ Hasbi juga mengajar di universitas Islam Indonesia Yogyakarta. ${ }^{30}$

Hasbi Ash-Shiddieqy tidak hanya memfokuskan diri sebagai seorang pengajar. Ia juga merambah karir di perpolitikan. Karir di bidang politi ini ia mulai pada tahun 1930, Ketika diangkat menjadi sebagai ketua Jong Islamiten Bond Cabang Aceh utara di Lhokseumawe. Ia menjadi anggota konstituante pada tahun 1955. Namun ia tidak menuruskan karirnya di bidang politik tersebut, sehingga ia pun Kembali lagi pada minatnya menjadi seorang pendidik. ${ }^{31}$

Kecintaannya sebagai seorang pendidik serta karirnya yang sangat menonjol di bidang pendidikan khususnya agama Islam, akhirnya ia mendapatkan pengakuan dan penghargaan. Adapun pengakuan itu berupa pemberian gelar Doctor Honoris Causa dari Universitas Islam Bandung pada tanggal 22 Maret 1975 dan dari IAIN Sunan Kalijaga sendiri pada tanggal 29 Oktober 1975. Di usia 71 tahun tepatnya pada tanggal 9 Desember 1975, Hasbi wafat dan dimakamkan di pemakaman Syarif Hidayatullah Ciputat Jakarta, Beliau meninggalkan seorang istri, dua orang putra dan dua orang putri.

Hasbi juga merupakan sosok pribadi yang sangat menghargai orang yang menyampaikan pendapat. Dia tidak marah apabila pendapatnya disanggah walaupun oleh anaknya sendiri. Bahkan dengan anaknya dia mengajak untuk berdiskusi yang kadangkal berlangsung seprti orang yang sedang bertengkar. Beliau juga mendiskusikan sesuatu yang sedang ia tulis dengan anak yang bertindak sebagai juru tulisanya dan korektor buku-bukunya. Apabila pendapat anaknya dirasa benar, dia mengakuinya. Namun jika salah, dia membetulkan dan menasihatinya agar belajar lebih banyak dengan membaca buku sebagaimana yang diperbuatnya. ${ }^{32}$

\footnotetext{
${ }^{29}$ Surahman Amin, Ferry Muhammadsyah Siregar, "Telaah atas Karya Tafsir di Indonesia: Studi atas Tafsir al-Bayan Karya T.M Hasbi Ash-Shiddieqy” Afkaruna Jurnal ilmu-ilmu KeIslaman, 2013. 3749.

${ }^{30}$ Tim Redaksi, Ensiklopedia Islam, Vol 2 (Jakarta: Ictiar Baru van Hoeve, 1994), 95. 1993), 95

${ }^{31}$ Masnun Thahir, . 126. Departemen Agama RI. Ensiklopedia Islam, (Jakarta: Anda Utama,

${ }^{32}$ Hasbi Ash-Shiddieqy, Dinamika Syariat Islam (Jakarta: Galura Pase, 2007), 17.
} 
Hasbi Ash-Shiddiqiey adalah sosok yang sangat disiplin dalam mengatur kehidupannya. Sehingga semua kegiatan itu agaknya harus terukur, sehingga beliau akan merasa sangat jengkel jika terdapat anggota keluarganya yang dianggapnya tidak sesuai dengan prinsip.prinsip kedisiplinan yang belaiu terapkan. Setidaknya ada tiga hal yang membuat beliau sangat jengkel. Pertama, bermalas-malas dan tidak menggunakan waktu senggang untuk dapat membaca. Istrinya juga harus membaca . Pada pukul setengah lima pagi, ia membangunkan keluarganya. Tidur siang tidak boleh dari satu jam. Kedua, pekerjaan tidak boleh ditunda. Semua pekerjaan tidak boleh ditunda. Semua pekerjaan harus dapat diselesaikan secepatnya. Pernah suatu Ketika anaknya harus mengetik naskahnya dari subuh sampai tengah malam dalam beberapa hari. Ia menghendaki agar anak-anaknya mencontohnya dalam bekerja keras. Ketiga, Semua buku-bukunya yang berada ditempat-tempat tertenutu, baik itu ada yang berada di rak maupun ditempat-tempat lainnya yang terbuka atau yang tertutup, harus berada ditempat yang telah disiapkan jangan ada yang tercecer atau berpindah tempat. Selepas Lelah pulang dari tempat kerja beliau tidak istirahat dahulu tapi memantau keadaan buku-bukunya, karena beliau marah jika selepas pulang kerja melihat buku-bukunya tidak ada dilokasi yang telah ditetapkan jika ia membutuhkan buku tersebut, walaupun sikap marah beliau tersebut ditunjukkan dengan hanya sekedar suara.

Dari beberapa ppengakuan muridnya, Hasbi merupakan sosok yang menarik dalam proses belajar dan mengajar, beliau menggunakan system diskusi, di sisi lain Hasbi juga dapat menjelaskan ide-ide yang tersimpan di pikirannya dengan baik. Penjelasannya mudah untuk dipahami.

\section{- Karya-Karya Hasbi Ash-Shiddiqiey}

Sosok Hasbi yang mencintai ilmu pengeahuan khususnya ilmu-ilmu agama tidak hanya dibuktikan dengan konsistensi beliau dalam mengajar tetapi dibuktikan juga dengan banyak melahirkan karya-karya. Selama kehidupan Hasbi, menurut catatan buku yang ditulisanya berjumlah 73 judul (142 jilid). Sebagian besar karyanya adalah dalam kajian fikih yaitu sebanyak 36 judul. Bidang lainnya, misalnya hadis. beliau telah melahirkan 8 judul buku mengenai hadis. Tafsir berjumlah 6 judul, tauhid berjumlah 5 judul. Sedangkan selebihnya sebanyak 17 judul merupakan tema-tema keislaman yang 
bersifat umum dan juga beliau aktif menulis artikel dimana telah menulis sebanyak 50 artikel dalam berbagai bidang, misalnya tafsir, hadis, fikih, ushul fikih. Serta pedoman ibadah. Di antara karya-karya beliau dianataranya :

- Dalam bidang Hadis dan Ilmu Hadis

Nama-nama buku yang berkaitan dengan hadis dan ilmu hadis yaitu: Sejarah dan Pengantar Ilmu Hadis, Beberapa Rangkuman Hadis, 2002 Mutiara Hadis sebanyak 8 Jilid, Problematika Hadis sebagai Dasar Pembinaan Hukum Islam, Pokok-pokok Ilmu Dirayah Hadis, 2 Jilid. Koleksi Hadis-Hadis Hukum, 11 Jilid, Rijalul Hadis, Sejarah Perkembangan Hadis .

- Dalam bidang Ilmu Al-Qur'an dan Tafsir.

Dalam bidang ini Hasbi telah menuliskan beberapa buku dengan judul-judul: Beberapa Rangkain Ayat (1952), Sejarah dan Pengantar Ilmu Al-Qur'an dan Tafsir (1954), Tafsir Al-Qur'an Majid An-Nur (30) Juz (1956), Tafsir al-Bayan (1966), Mukjizat Al-Qur'an (1966), Ilmu-Ilmu Al-Qur'an: Media Pokok dalam Menafsirkan AlQur'an (1972).

- Dalam bidang fikih/Ushul fikih.

Judul-judul bukunya antara lain: Sejarah Peradilan Islam (1950), Tuntunan Qurban (1950), Pedoman Shalat, Hukum-Hukum Fikih Islam, Pengantar Hukum Islam (1953), Pedoman Zakat, Al-Ahkam (Pedoman Muslimin) (1953), Pedoman Puasa, Kuliah Ibadah, Pemindahan Darah (blood Tranfusion) Dipandang dari sudut Hukum Islam (1954), Ictishar Tuntunan Zakat dan Fitrah (1958), Syariat Islam Menjawab Tantangan Zaman (1961), Peradilan dan Hukumk Acara Islam, Poligami Menurut Syariat Islam, Pengantar Ilmu Fikih (1967), Baitul Mal Sumber-Sumber dan Penggunaan Keuangan Negara Menurut Ajaran Islam (1968), Zakat sebagai salah satu Unsur pembinan Masyarakat Sejahtera (1969), Asas-asasa Hukum Tata Negara Menurut Syariat Islam, (1969), Sejarah Pertumbuhan dan Perkembangan Hukum Islam (1971), Hukum Antar golongan dalam fikih. Perbedaan Mathla' Tidak Mengharuskan Kita Berlainan pada Memulai Puasa, Ushul Fikih, Ilmu Kenegaraan dalam Fikih Islam (1971), Beberapa problematika Hukum Islam (1972), Kumpulan Soal Jawab (1973), 
Pidana Mati dalam Syari'at Islam, Sebab, sebab Perbedaan Faham Para Ulama dalam Menetapkan Hukum Islam, Pokok-pokok Pegangan Imam-Imam Mazhab dalam Membina Hukum Islam, Pengantar Fikih Muamalah, Fakta-Fakta Keagunangan Syuariat Islam (1974), Falsafah Hukum Islam (1975), Fikih Islam Mempunyai Daya Elastis, Lengkap, Bulat dan Tuntas (1975), Pengantar Ilmu Perbandingan Mazhab (1975), Ruang Lingkup Ijtihad Para Ulama dalam Membela Hukum Islam (1975), Dinamika dan Elastisitas Hukum Islam (1976), Pedoman Haji. ${ }^{33}$

Dalam bidang Tauhid./ilmu Kalam beliau menulis buku, yaitu: Pelajaran Tauhid, Hakikat Islam, Unsur-unsur agama

\section{A. Review Karya-Karya Hasbi Ash-Shiddiqey Tentang Ilmu Al-Qur'an dan Tafsir}

\section{Buku Sejarah dan Pengantar Ilmu Al-Qur'an dan Tafsir}

\begin{tabular}{|l|l|l|}
\hline No & Tag & Isi \\
\hline 1 & Pengarang & Prof. Dr.T.M. Hasbi Ash-Shiddiqey \\
\hline 2 & Tempat Terbit & Jakarta \\
\hline 3 & Tahun terbit & 1992 \\
\hline 4 & Penerbit & PT. Bulan Bintang \\
\hline 5 & Cetakan Ke- & Cetakan ke 14, dan cetakan pertama kali tahun 1954 \\
\hline 6 & Jumlah Halaman & 290 \\
\hline 7 & Segmentasi Buku & Umum dan Mahasiswa \\
\hline 8 & Nomor ISBN & $979-418-018-1$ \\
\hline 9 & Jumlah Bahagian & Pengantar dan 6 Bahagian \\
\hline 10 & Jumlah Bab & Terdiri dari 19 bab \\
\hline
\end{tabular}

Buku yang direview ini merupakan cetakan ke-14 yang diterbitkan pada tahun 1992 . Adapun cetakan ke. Motivasi penyusunan buku ini nampaknya sebagai pelengkap bahan bacaan untuk mahasiswa khususnya dalam bidang studi ilmu AlQur'an dan Tafsir, dimana kebanyakan buku-buku referensi mengenai Ilmu keIslaman khususnya dalam bidang Ilmu Al-Qur'an dan Tafsir kebanyakan ditulis dalam Bahasa Arab dan belum tentu semua mahasiswa paham. Sehingga perlu menyususn satu buku

\footnotetext{
${ }^{33}$ N. Shiddiqi, Fiqh Indonesia: Penggagas dan Gagasannya ..., 274-276.
} 
referensi dalam Bahasa Indonesia sehingga dapat membantu mahasiswa agar memahaminya dengan mudah ${ }^{34}$

Buku Sejarah Pengantar Ilmu Al-Qur'an dan Tafsir ini bisa dikatakan sebagai sebuah buku yang disusun oleh Hasbi Ash-Shiddiqey untuk menjadi referensi atau bahan bacaan. Didalamnya Hasbi mencoba menghadirkan seluk beluk keilmuan AlQur'an dan menyusunnya secara sistematis. Ini bisa dilihat dari modul penyusunannya di awali dengan Pengantar. Dalam Pengantar tersebut membahas mengenai Ta'rif Kitab, Al-Qur'an dan Wahyu. Bahagian Pertama terdiri dari empat Bab. Bab pertama membahas mengenai Al-Qur'an Pada Masa Nabi Muhammad SAW. Bab kedua berisi mengenai soal-soal yang bersangkut paut dengan Nuzulul Quran. Bab ketiga membahas mengani Usaha-usaha Rasul dan Para Sahabat sekitar menyampaikan Al-Qur'an. Bab keempat membahas tentang rupa-rupa Qira'at Al-Qur'an . ${ }^{35}$

Bagian kedua membahas Sejarah Mengumpulkan Shuhuf-Shuhuf Al-Qur'an terdiri dari tiga bab. Bab pertama membahas mengenai Al-Qur'an pada masa Abu Bakar dan Umar. Bab kedua membahas Al-Qur'an pada Ustman. Bab ketiga membahas tentang sekitar tulisan Al-Qur'an. Bagian ketiga membahas tentang Ilmu-Ilmu AlQur'an yang Perlu dipelajari oleh Para Mufassirin dan Sejarahnya, dalam bahagian ketiga ini terdiri dari dua bab. Bab pertama membahas tentang Ilmu-ilmu Dirayah dan Riwayah Al-Qur'an, bab kedua membahas tentang Problema Naskhul Quran.

Bahagian yang keempat membahas mengenai Sifat-Sifat Al-Qur'an, Rutbahnya dan Maksud-maksdunya yang didalamnya terdiri dari tiga bab. Bab pertama berbicara tentang Sifat-Sifat Al-Qur'an. Bab kedua membahas tentang beberapa contoh Uslub AlQur'an. Bab ketiga membahas tentang Al-Qur'an Dasar asasi yang terpokok bagi Islam. Bahagian kelima membahas tentang Ta'rif Tafsir, Ta'wil, Qaedah-Qaedah, IstilahIstilah dan ilmu-ilmu yang diperlukan untuk menafsirkan Al-Qur'an. dalam bahagian ini terdiri dari empat bab. Bab pertama membahas mengenai Ta'rif tafsir dan Takwil. Bab kedua membahas tentang Ilmu-ilmu yang Diperlukan oleh seseorang Penafsir. Bab ketiga membahs tentang beberapa istilah tafsir terakhir bab empat membahas mengenai

\footnotetext{
${ }^{34}$ Hasbi Ash-Shiddieqy, Sejarah dan pengantar Ilmu Alquran dan Tafsir, (Jakarta: PT.Bulan Bintang, 1992), xiii

${ }^{35}$ Hasbi Ash-Shiddieqy, Sejarah dan pengantar Ilmu Alquran..., vi-vii.
} 
Tafsir dari Abad ke Abad, sejarah perkembangan Tafsir. Bahagian terakhir atau keenam membahas tentang Biografi Ulama-ulama Al-Qur'an dimana dalam bahagian ini terdiri dari tiga bab. Bab pertama membahas tentang biografi ulama-ulama Al-Qur'an dari sahabat. Bab kedua, membahas tentang biografi ulama-ulama Al-Qur'an sesudah sahabat. Bab ketiga membahas tentang sejarah Ahli-Ahli Tafsir dan Qiraat ${ }^{36}$

Berdasarkan buku Sejarah Ilmu Al-Qur'an Tafsir yang telah disebutkan di atas tampak bahwa merupakan sebuah usaha yang konsisten dan sitematis yang dilakukan oleh Hasbi Ash-Shiddiqey dalam mengemukakan berbagai sendi kajian Ilmu Al-Qur'an dan Tafsir. Dimulai dengan definisi-definisi Al-Qur'an kemudian sejarah penulisan AlQur'an dilanjutkan dengan studi ilmu-ilmu Al-Qur'an ('Ulumul Qur'an). Juga didalamnya membahas tentang perkembangan tafsir Al-Qur'an serta tokoh-tokoh mufassir Al-Qur'an. Penulis beranggapan buku ini dapat dikatakan sebagai suatu buku mengenai studi ilmu Al-Qur'an dan Tafsir serta bagian-bagiannya yang ditulis dalam Bahasa Indonesia yang terlengkap dari segi pembahasan pada masanya tepatnya pada masa pertama kali buku ini diterbitkan yaitu pada tahun 1954 oleh penerbit CV Bulan bintang. Dan merupan salah satu buku yang berkontribusi besar terhadap kejian studi ilmu Al-Qur'an dan tafsir di Indonesia pada masanya.

\section{Buku Ilmu-Ilmu Al-Qur'an (Ulumul Quran).}

Salah satu karya beliau lainnya yang membahas mengenai studi Ilmu Al-Qur'an adalah Ilmu Al-Qur'an dan media pokok dalam menafsirkan Al-Qur'an atau dikenal dengan Ilmu-Ilmu Al-Qur'an. Buku ini pertama kali dicetak pada tahun 1972. Namun yang penulis angkat disini adalah cetakan ke-3 yang diterbitkan pada tahun 2009.

\footnotetext{
${ }^{36}$ Hasbi Ash-Shiddieqy, Sejarah dan pengantar Ilmu Alquran...., ix-xii.
} 


\begin{tabular}{|l|l|l|}
\hline No & Tag & Isi \\
\hline 1 & Pengarang & Prof. Dr.T.M. Hasbi Ash-Shiddiqey \\
\hline 2 & Tempat Terbit & Semarang \\
\hline 3 & Tahun terbit & 2009 \\
\hline 4 & Penerbit & Pustaka Rizki Putra \\
\hline 5 & Cetakan Ke- & Cetakan ke 14, dan cetakan pertama kali tahun 1954 \\
\hline 6 & Jumlah Halaman & Xvi + 300 \\
\hline 7 & Segmentasi Buku & Umum dan Mahasiswa \\
\hline 8 & Nomor ISBN & 978-979-9430-58-8 \\
\hline 9 & Jumlah Bahagian & 15 Bahagian \\
\hline
\end{tabular}

Buku ini terdiri dari 15 Bahagian. Setiap bahagiannya terdiri dari dari beberapoa judul. Bagian Pertama mengenai Sejarah Perkembangan Ilmu Al-Qur'an terdiri dari, Ta'rif Al-Qur'an, Timbulnya istilah-istilah ilmu Al-Qur'an, Pertumbuhan ilmu-ilmu AlQur'an, ilmu-ilmu Al-Qur'an pada masa rasul dan khulahurrasyidin, Tokoh-tokoh tafsir pada abad kedua, ilmu-ilmu Al-Qur'an yang tumbuh dalam abad ketiga hijriah, ilmuilmu Al-Qur'an yang timbul pada abad keempat hijriah, ilmu-ilmu Al-Qur'an yang tumbuh paada abad ke lima hijriah, ilmu -ilmu Al-Qur'an yang tumbuh pada abad keenam dan ketujuh hijriah, ilmu-ilmu Al-Qur'an yang tumbuh pada abad ke delapan dan kesembilan hijriah, ilmu-ilmu Al-Qur'an yang tumbuh dalam abad keempat belas hijriah.

Bagian kedua berbicara mengenai sebab-sebab turunnya ayat Al-Qur'an. Bagian ketiga berbicara mengenai surat yang diturunkan di Makkah dan Madinah.Bagian keempat huruf-huruf yang digunakan pada pembuka surat (Fawatih as-Suwar), Bahagian kelima berbicara mengenai cara-cara membaca Al-Qur'an, Bahagian keenam, Ayat-Ayat yang menghapuskan dan dihapuskan hukumnya (ilmu Nasakh dan Mansukh). Bagian ketujuh berbicara mengenai cara-cara menulis lafal-lafal Al-Qur'an (Ilmu Rasm Al-Qur'an). Bagian kedelapan membahas tentang Ayat yang Muhkam dan Mutasyabihah). Bagian kesembilan membahas tentang perumpamaan-perumpamaan di Dalam Al-Qur'an (Ilmu Amstalul Quran). Bagian kesepuluh membahas tentang sumpah di Dalam Al-Qur'an (Ilmu Aqsamul Quran). Bagian Kesebelas membahas tentang kisah-kisah dalam Al-Qur'an (Ilmu Qashash Al-Qur'an). Bagian Kedua belas 
membahas tentang debat dalam Al-Qur'an (Ilmu Jadal Al-Qur'an). Bagian Ketigabelas membahas tentang ilmu tafsir. ${ }^{37}$

Buku ini merupakan buku mengenai studi Al-Qur'an dan Tafsir yang kedua setelah buku sejarah dan pengantar ilmu Al-Qur'an dan Tafsir. Buku kedua ini berisi mengenai studi ilmu Al-Qur'an yang lebih komplek dan mendalam mengenai studi ilmu-ilmu Al-Qur'an. bisa dibandingkan dengan buku ilmu Al-Qur'an dan tafsir sebelumnya. Buku ini bisa dikatakan sebagai penyempurnaan pembahasan dari buku yang telah diterbitkan sebelumnya

\section{Tafsir al-Qur'anul Majid An-Nur}

Tafsir Al-Qur'anul Majid An-nur atau dikenal dengan Tafsir An-nur merupakan salah satu kitab tafsir karya Hasbi Ash-Shiddiqey yang fenomenal. Kitab tafsir ini ditulis pada tahun 1952-1961 disela-sela kesibukan beliau sebagai seorang pengajar dan pendidik. Kitab Tafsir an-Nur pertama kali terbit pada tahun 1956, cetakan pertama ini terdiri dari 30 juz. Sedangkan dalam cetakan yang kedua yang diterbitkan pada tahun 1965. Kemudian kitab tafsir dicetak Kembali dan diterbitkan edisi kedua pada tahun 2000. Sebelum dicetak kitab tafsir an-Nur ini diedit oleh Prof. Dr. H. Nouruzzaman dan H.Z. Fuad Hasbi Ash-Shiddiqey yang merupakan kedua putra dari Hasbi AshShiddieqy.

Penulisan kitab Tafsir an-Nur memiliki latar belakang semangat yang besar dimana salah satu motivasi Hasbi dalam Menyusun kitab ini diantaranya, merupakan salah satu upaya dalam mengembangkan kebudayaan Islam khususnya terkait dengan perkembangan perguruan-perguruan tinggi Islam Indonesia. Motivasi selanjutnya ialah timbulnya rasa ingin menghadirkan kitab tafsir yang berbahasa Indonesia ditengahtengah masyarakat. Dimana kitab-kitab tafsir yang sudah ada kebanyakan ditulis dalam Bahasa Arab sehingga membuat masyarakat Indonesia sulit memahami kitab tafsir tersebut dikarenakan minimnya kemampuan Bahasa Arab. Karenanya Hasbi AshShiddiqey menghadirkan kitab Tafsir An-Nur.

${ }^{37}$ T.M Hasbi Ash-Shiddieqy, Ilmu-Ilmu Alquran, (Semarang: Pustaka Rizki Putra, 2009), cet ke- 
Selanjutnya untuk memurnikan tafsir Al-Qur'an dari para penulis Barat, karena buku-buku tafsir yang ditulis oleh para sarjana Barat tidak dijamin bersih dari kebersihan dan kesucian jiwa. Hasbi bependapat bahwa, para penulis Barat lebih cenderung menulis tafsir hanya sebagai suatu pengetahuan bukan sebagai suatu akidah yang mereka pertahankan, tentunya ini berbeda jauh dengan tafsir yang ditulis oleh para ulama. Indonesia menghayati perkembangan tafsir dalam Bahasa persatuan Indonesia. Kehadiran tafsir ini memperbanyak referensi dan khazanah Islam dalam masyarakat Indonesia. ${ }^{38}$

Adapun landasan Hasbi saat menulis kitab Tafsir An-Nur ini adalah berlandaskan pada sumber-sumber ayat Al-Qur'an, Riwayat Nabi SAW, Riwayat sahabat dan tabi'in, dan menggunakan beberapa kitab tafsir rujukan. Kitab tafsir yang dijadikan kitab tafsir rujukan yaitu kitab tafsir yang mu'tabar. Di mana kitab tafsir mu'tabar ini di artikan oleh Hasbi sebagai kitab induk, Kitab-kitab tafsir tersebut di antaranya 'Umdat al-Tafsir karya Ibn Katsir, Tafsir al-Manar karya Muhammad Abduh dan Muhammad Rasyid bin 'Ali Rida', Tafsir al-Qasimiy dengan judul aslinya Mahasin al-Ta'wil karya Muhammad Jamal al-Din al-Qasimiy, Tafsir al-Maraghi karya Mustafa al-Maraghi dan Tafsir wadhih, dalam hal terjemah dan alih Bahasa, Hasbi berpedoman pada beberapa tafsir seperti Tafsir Abu Su'ud yang berjudul Irsyad al-Aql al-Salim ila mazaya al-kitab al-karim, tafsir milik Shiddiqy Hasan Khan dan Tafsir al-Qasimy. ${ }^{39}$

Sistematika yang ditempuh oleh Hasbi Ash-Shiddiqey dalam Menyusun kitab tafsir ini, di anataranya: menyebutkan satu, dua atautiga ayat dari Al-Qur'an sesuai dengan urutannya, kedua, menerjemahkan Kalimat-kalimat yang mempunyai dua makna terjemahan dengan lengkap. Ketiga, menafsirkan ayat secara tematik kemudian menafsirkannya dengan hadis-hadis atau riwayat lain, menyebutkan Asbab an-Nuzul, Menyebutkan kategori Makkiyah dan Madaniyyah, juga mengemukakan munasabah keterkaitan antara satu ayat dengan ayat lainnya. Terakhir yaitu dengan menyimpulkan apa yang telah ditafsirkan sebelumnya. ${ }^{40}$ Corak yang tergambarkan dalam Tafsir An-

\footnotetext{
38 Teungku Muhammad Hasbi Ash-Shiddiqey, Tafsir al-Qur'anul Majid An-Nur, jilid I (Semarang: Pustaka Rizki Putra), xi.

${ }^{39}$ Teungku Muhammad Hasbi Ash-Shiddiqey, Tafsir al-Qur'anul..., xv

${ }^{40}$ Yunus Hasan Abidu, Tafsir al-Quran, Sejarah Tafsir dan Metode Para Mufassir (Jakarta: Gaya Media Pratama, 2007), 3
} 
Nur ialah corak umum. Metode yang digunakan oleh Hasbi dalam menulis kitab Tafsir An-Nur ini menggunakan metode ijmali, terkadang juda dalam ayat-yat tertentu beliau tafsirkan dengan metode maudhu'i. Bisa dipahami dari pernyataan beliau.

Menerangkan ayat-ayat yang terdapat di lain-lain surat, atau tempat yang dijadikan penafsiran bagi ayat yang sedang ditafsirkan, atau yang sepokok, supaya mudahlah pembaca mengumpulkan ayat-ayat yang sepokok, dan dapatlah ayat-ayat itu ditafsirkan oleh ayat-ayat sendiri. ${ }^{41}$

Kitab Tafsir an-Nur sebagaimana yang telah dijelaskan di atas, menunjukkan kesungguhan seorang sosok Hasbi Ash-Shiddiqey dalam menghadirkan Tafsir AlQur'an yang bertujuan untuk dapat dipahami oleh masyarakat secara umum. Kehadiran kitab Tafsir ini juga pada masanya menjadi suatu kemajuan dalam bidang Tafsir.

\section{Tafsir al-Bayan}

Tafsir al-Bayan ini merupakan karya tafsir yanag ditulis setelah karyanya yang pertama yaitu kitab Tafsir An-Nur. Tafsir al-Bayan ini selesai ditulis pada tahun 1966. Penulisan Tafsir al-Bayan didasari atas keinginannya sendiri sebagaimana pernyataan yang tertulis dalam kata pengantar.

Dengan inayah Allah Taala dan Taufiq-Nya, setelah saya selesai dari Menyusun Tafsir An-Nur yang menterjemahkan ayat dan menafsirkannya, tertarik pula hati saya kepada menyusun Al-Bayaan. ${ }^{42}$

Kehadiran kitab Tafsir al-Bayan ini merupakan penyempurnaan dari penerjemahan yang ada di dalam kitab tafsir sebelumnya yakni kitab Tafsir An-Nur. Hal ini bisa disimak dari pernyataan beliau sendiri,

Di dalam menerjemahkan ayat dalam tafsir "An-Nur", saya menempuh jalan cepat, jalan yang lazim ditempuh oleh penterjemah-penterjemah lain, Karenanya terjemahan ayat-ayat dalam tafsir "An-Nur", tidak menterjemahkan seluruh lafaz, apalagi lafaz-lafaz yang harus diungkapkan. ${ }^{43}$

Juga pada pernyataan berikutnya,

Maka setelah saya memperhatikan perkembangan penerjemahan Al-Qur'an akhir-akhir ini, serta meneliti secara tekun terjemahan-terjemahan itu, nyatalah

\footnotetext{
${ }^{41}$ Teungku Muhammad Hasbi Ash-Shiddiqey, Tafsir al-Qur'anul..., xiii.

${ }^{42}$ T.M Hasbi Ash-Shiddiqey, Tafsir al-Bayaan, Juz I (Bandung: Al-Ma'aarif, t.th.), 7

${ }^{43}$ T.M Hasbi Ash-Shiddiqey, Tafsir al-Bayaan.., 7
} 
bahwa banyak terjemahan kalimat yang perlu ditinjau dan disempurnakan. Oleh Karenanya, dengan memohon taufiq daripada Allah Taala, saya menyusun sebuah terjemah yang lain dari yang sudah-sudah. ${ }^{44}$

Adapun sistematika penulisan tafsir terhadap kitab tafsir al-Bayan atau yang disebut oleh Hasbi sebagai “Khiththah-Khiththah”-nya yakni:

a. Menerjemahkan ma'na lafaz dan menterjemahkan kalimat-kalimat yang ditaqdirkan, baik di awal, dipertengahannya, maupun di akhirnya.

b. Menterjemahkan kalimat-kalimat yang mempunyai dua sterjemahan dengan lengkap, dengan menyebut terjemahan kedua dalam (...)

c. Menterjemahkan ma'na ayat yang dapat diterjemahkan lebih dari satu macam, lantaran berlainan I'rab dan sebagainya. Terjemahan yang kedua diletakkan dalam not, diawali oleh perkataan :" dapat juga diterjemahkan..."

d. Menterjemahkan lafaz-lafaz yang ditaqdirkan, atau yang merupakan kalimatkalimat pelancar, dalam dua streep-....-.

e. Menerangkan pendapat-pendapat ulama di dalam mema'nakan sesuatu ayat, atau kalimat yang berbeda-beda, ditempat-tempatyang saya pandang perlu dan penting diberi perhatian, karena kuatnya dalil. Hal ini saya sebut dalam noot,

f. Menterjemahkan lafaz-lafaz sifat Allah swt yang sewazan "fa'ul" yang memfaedahkan "kebanyakan" dan "kesangatan" dengan mengawali terjemahannya dengan "yang sangat" atau " yang sangat banyak" atau " yang maha", seperti ghafur =Maha Pengampun atau yang sangat pengampun atau yang banyak mengampun. Lafaz-lafaz sifat yang sewajan fa'il, yang memfaedahkan $t$ subut= tetap dan terus-menerus, bukan menerangkan banyak atau sangat, saya awali terjemahannya dengan "yang senantiasa", atau " yang tetap" 45

Metode yang digunakan oleh Hasbi diddalam kitab Tafsir al-Bayan adalah metode tahlili, sabagaimana yang ditelaah oleh Sulaiman Ibrahim bahwa corak yang digunakan oleh Hasbi dalam Tafsir al-Bayan adalah bercorakan al-Ra'yu dan fikih, atau Bahasa lainnya bercorak pemikiran dan hukum. Adapun Teknik penafsirannya T.M Hasbi Ash-Shiddieqy dalam menjelaskan ayat-ayat Al-Qur'an, beliau menerangkan makna-makna ayat yang tercakup di dalamnya, dan menguraikannya secara berurutan ayat demi ayat, surah demi surah sesuai dengan urutannya di dalam Mushaf, yakni mulai dari surah al-Fatihah sampai surat an-Nas. ${ }^{46}$

\footnotetext{
${ }^{44}$ T.M Hasbi Ash-Shiddiqey, Tafsir al-Bayaan..., .7

${ }^{45}$ Sulaiman Ibrahim, "Khazanah Tafsir Nusantara: Telaah atas Tafsir al-bayan karya T.M Hasbi Ash-Shiddiqey" Jurnal Farabi, Vol 18. No. 2. 2018. 109

${ }^{46}$ Sulaiman Ibrahim, Khazanah Tafsir Nusantara..., 110.
} 
Penjelasan di atas merupakan gambaran umum mengenai Tafsir al-Bayan. Tafsir ini hadir sebagai penyempurnaan atas terjemahan-terjemahan pada kitab tafsir sebelumnya yakni kitab Tafsir an-Nur. Secara umum dari segi penulisan Teknik yang digunakan hampir sama dengan Teknik yang digunakan dalam menyusun kitab Tafsir an-Nur.

Dalam pendekatan sejarah, Hasbi Ash-Shiddieqy hidup dan dibesarkan di tengah-tengah keadaan yang terjadi pada masyarakat Indonesia, dimana pada saat itu di jawa tumbuh Gerakan pembaharuan Islam yang meniupkan pula semangat kebangsaan Indonesia serta anti penjajah. Semangat ini juga yang tumbuh dalam diri Hasbi AshShiddiey. Secara umum kondisi tersebut ialah masa kebangkitan Islam yang seiring dengan tumbuhnya ide nasionalisme baru di wilayah Indonesia. ${ }^{47}$ Secara umum motivasi besar buku-buku ilmu Al-Qur'an dan Tafsir karyanya ditulis dalam Bahasa Indonesia adalah sebagai upaya untuk memudahkan masyarakat dan mahasiswa untuk memahami buku-buku ilmu Al-Qur'an dan Tafsir, karena menurutnya pengetahuan Bahasa Arab pada masa itu sangat rendah baik dari sebahagian besar masyarakat maupun dikalangan mahasiswa pada saat itu. Di sisi lain, penulis melihat upaya Hasbi dengan menghadirkan buku-buku Ilmu Al-Qur'an dan Tafsir dalam Bahasa Indonesia merupakan wujud dari unsur-unsur sikap nasionalisme kebangsaan Indonesia, alasan ini timbul dengan melihat konteks keadaan sosial dimana pada saat itu lahirnya semangat Nasionalisme.

\section{Kesimpulan}

Hasbi Ash-Shiddiqey yang lahir pada tahun tanggal 10 Maret 1904 merupakan sosok cendikiawan dan ulama yang sangat berjasa dalam pengembangan studi IlmuIlmu KeIslaman, beliau tidak hanya fokus dalam satu bidang ilmu keagamaan saja tapi juga lebih dari itu. Hal ini bisa dibuktikan dari karya-karyanya yang tidak hanya membahas tentang satu keilmuan saja yakni Al-Qur'an dan Tafsir, juga beliau melahirkan karya-karya dalam bidang keilmuan Islam yang lainnya seperti fikih, Ushul Fikih, Hadis, dan Kalam. Kesungguhan beliau dalam mengajar dan menjadi seorang pendidik juga beliau curahkan sampai akhir hayatnya.

\footnotetext{
47 Musnan Tahir, Pemikiran T.M Habi Ash-Shiddiqey sumber hukum Islam...,127
} 
Karya-Karya beliau dalam bidang Ilmu Al-Qur'an dan Tafsir, yakni. Sejarah dan Pengantar Ilmu Al-Qur'an dan Tafsir, ilmu-ilmu Al-Qur'an (Ulumul Quran) Kitab Tafsir Al-Qur'an Majid An-Nur dan Tafsir al-Bayan merupakan kesungguhan beliau dalam mengembang studi ilmu Al-Qur'an dan Tafsir di Indonesia. Ketiga karya tersebut ditulis dalam Kurun Waktu kedua 1951-1980 . karya-karya tersebut bisa dikatakan sebagai suatu kontribusi besar dalam keilmuan Al-Qur'an dan tafsir di Indonesia walaupun memang pada kurung waktu tersebut terdapat beberapa Tokoh lainnya, namun menurut hemat penulis Hasbi termasuk sosok ulama dan cendikiawan muslim yang sangat produktif dimana beliau tidak hanya menulis buku pengantar studi AlQur'an dan tafsir, ilmu-ilmu Al-Qur'an (Ulumul Quran) tapi beliau juga menulis dua kitab tafsir, Tafsir an-Nur dan al-Bayan. Lahirnya karya-karya ini merupakan wujud perhatiannya terhadap minimnya kehadiran buku Ilmu Al-Qur'an dan Tafsir yang bernuansa Bahasa Indonesia pada saat itu.

\section{DAFTAR PUSTAKA}

A.M. Ismatullah, Penafsiran M.Hasbi Ash-Shiddieqy Terhadap Ayat-Ayat Hukum Dalam Tafsir An-Nur, Dalam MAZAHIB, Vol.XIII. No.2. 2014.

Hasbi Ash-Shiddieqy, Dinamika Syariat Islam, Jakarta: Galura Pase, 2007.

Hasbi Ash-Shiddieqy, Sejarah dan pengantar Ilmu Al-Qur'an dan Tafsir, Jakarta: PT.Bulan Bintang, 1992.

Izzaa Rohman Nahrowi, Karakteristik Kajian al-Qur'an di Indonesia, dalam jurnal Refleksi, vol. v, No.2.

Masnun Tahir, Pemikiran T.M Habi Ash-Shiddiqey sumber hukum Islam dan Relevansinya dengan Pemikiran Hukum Islam di Indonesia, Dalam jurnal alAhwal, Vol. 1, No. 1, 2008.

Aziz Dahlan (ed), Ensklipodia Hukum Islam, Jakarta: PT Ikhtiar Baru Van Hoeve.

Masnun Thahir, h. 126. Depaetemen Agama RI. Ensiklopedia Islam, Jakarta: Anda Utama, 1993.

Muhsin, Kajian Karya-Karya Ulum Al-Qur'an di Indonesia Dari Tahun 2009-2017, dalam jurnal Syahadah, Vol, VI, No. 1. April 2018. 
Nashiruddin Baidan, Perkembangan Tafsir Al-Qur'an di Indonesia, Solo, Tiga Serangkai Putra Mandiri : 2003.

Nourouzzaman Shiddieqy, Fikih Indonesia: Penggagas dan Gagassannya, Yogyakarta, Pustaka: Pelajar, 1997.

Sudariyah, Kontruksi Tafsir Al-Qur'an Majid An-Nur, dalam SHAHIH, Vol.3, No.1.

Sulaiman Ibrahim, Khazanah Tafsir Nusantara: Telaah atas Tafsir al-Bayan karya T.M Hasbi Ash-Shiddiqey, dalam jurnal Farabi, Vol 18. No. 2.

T.M Hasbi Ash-Shiddieqy, Ilmu-Ilmu Al-Qur'an, Semarang: Pustaka Rizki Putra, 2009 , cet ke-3.

Teungku Muhammad Hasbi Ash-Shiddiqey, Tafsir al-Qur'anul Majid An-Nur, jilid I, Semarang: Pustaka Rizki Putra.

Tim Redaksi, Ensiklopedia Islam, Vol 2. Jakarta: Ictiar Baru van Hoeve, 1994.

Yunus Hasan Abidu, Tafsir al-Quran, Sejarah Tafsir dan Metode Para Mufassir, Jakarta: Gaya Media Pratama, 2007.

Setyosar Punaji, Metode Penelitian Pendidikan dan Pengembangan, Jakarta: PT. Kencana, 2010.

Aan Supian. Kontribusi Pemikiran Hasbi Ash-Shiddiqiey Dalam Kajian Ilmu Hadis. Dalam jurnal Mutawatir, Vol.4, No.2.

Federspiel, Kajian Al-Qur'an di Indonesia dari Mahmud Yunus hingga Quraish Shihab, Bandung: Mizan 1996.

Sulaiman Ibrahim, Khazanah Tafsir Nusantara: Telaah atas Tafsir al-bayan karya T.M Hasbi Ash-Shiddiqey, dalam jurnal Farabi, Vol 18. No. 2.

Surahman Amin, Ferry Muhammadsyah Siregar, Telaah atas Karya Tafsir di Indonesia: Studi atas Tafsir al-Bayan Karya T.M Hasbi Ash-Shiddieqy, dalam Afkaruna Jurnal ilmu-ilmu KeIslaman.

T.M Hasbi Ash-Shiddiqey, Tafsir al-Bayaan, Juz I, Bandung: Al-Ma'aarif, t.th. 